\title{
KAJIAN BETON POLIMER MENGGUNAKAN BAHAN CAMPURAN PEREKAT RESIN TERHADAP KUAT TEKAN BETON DENGAN PENGUJIAN KUAT TEKAN BETON
}

\author{
Zaid Zabbar \\ Muhamad Ryanto \\ Email: mryanto@yahoo.com
}

\begin{abstract}
ABSTRAK
Beton polimer adalah material komposit dimana seluruh perekatnya terdiri dari polimer organik sintetis. Komposit ini biasa dikenal dengan sebutan beton resin sintetis, beton resin plastik atau beton resin. Zat perekat yang dipakai dalam pembuatan beton polimer dalam penelitian ini yakni Epoxy Resin dan Polymer Polygrout dengan perbandingan yang telah ditentukan standarnya. Jenis epoxy yang digunakan adalah Epoxy Resin dan Polimer Polygrout yang merupakan jenis polimer recycled polyethylene thereptalate resin (hasil daur ulang plastic bekas). Penelitian yang telah dilakukan adalah pembuatan benda uji dan pengujian mutu beton diperoleh nilai kuat tekan Epoxy Resin $\mathrm{fc}^{\prime}=$ 57,2 Mpa dengan komposisi Epoxy + Kerikil, fc' $=45,7$ Mpa dengan komposisi Epoxy $+75 \%$ kerikil $+25 \%$ pasir dan $\mathrm{fc}^{\prime}=49,0 \mathrm{Mpa}$ dengan komposisi Epoxy $+50 \%$ kerikil $+50 \%$ pasir. Penelitian pada Polymer Polygrout diperoleh nilai kuat tekan fc' $=29,5$ Mpa dengan komposisi Polygrout + kerikil, fc' $=36,6$ Mpa dengan komposisi Polygrout $+75 \%$ kerikil $+25 \%$ pasir dan $\mathrm{fc}^{\prime}=39,0$ dengan komposisi Polygrout $+50 \%$ kerikil $+50 \%$ pasir. Penelitian ini bertujuan untuk mengetahui karakteristik, mengetahui pengaruh kuat tekan beton, mengetahui pengaruh penggantian zat perekat, mengetahui jika ditambahkan filler ke dalamnya. Penelitian dengan menggunakan cetakan kubus berukuran $15 \times 15 \times 15 \mathrm{~cm}$ sebanyak 6 buah benda uji. Komposisi campuran beton bervariasi antara lain 0\%, 25\%, hingga 50\% campuran dengan kuat tekan rencana fe' $=30 \mathrm{Mpa}$.
\end{abstract}

Kata Kunci: Beton polimer, Epoxy Resin dan Polimer Polygrout

\section{PENDAHULUAN}

Indonesia bahkan dunia kini sudah tidak dapat luput lagi dari pembangunan infrastrukturnya. Pekerjaan konstruksi meningkat seiring perkembangan dari zaman ke zaman. Begitupun kemajuan teknologinya dari tahun ke tahun. Salah satu dari banyak kemajuan yaitu beton yang merupakan salah satu bahan konstruksi utama yang paling banyak digunakan dalam proyek konstruksi.
Beton merupakan campuran semen, agregat halus, agregat kasar dan air. Beton sangat terkenal dengan kekuatannya dalam menahan beban yang berat. Selain itu beton juga mudah dalam pengerjaan, mudah dibentuk, memiliki keawetan maupun sifat beton lainnya tergantung pada sifat bahan-bahan dasar, nilai perbandingan bahan-bahannya, cara pengadukan, cara penuangan adukan 
beton, cara pemadatan, dan cara perawatan selama proses pengerasan.

Jenis epoxy yang digunakan adalah Epoxy Resin dan Polimer Polygrout yang merupakan jenis polimer recycled polyethylene thereptalate resin (hasil daur ulang plastic bekas). Dimana isian Polimer Polygrout ini diperoleh dari hasil limbah pembakaran batubara PLTU Suralaya, tanah liat bakar diperoleh dari salah satu sumber komersial di Cilacap. Penelitian yang telah dilakukan adalah untuk memperoleh bahan beton alternatif yang mempunyai bobot yang lebih ringan. Polimer Polygrout ini memanfaatkan hasil pembakaran batubara (fly ash), bahan daur ulang plastik bekas dan potensi material bumi dominan yaitu tanah liat. Berdasarkan pembahasan diatas, yang selanjutnya disebut beton polimer maka penulis bermaksud untuk menambahkan epoxy pada beton normal yaitu sebagai pemanfaatan bahan kimia yang jarang dipakai untuk penelitian beton. Oleh karena itu, penulis ingin melakukan penelitian mengenai pengaruh penggunaan zat epoxy terhadap beton normal yang ditinjau dari parameter pengujian kuat tekan beton.

\section{TEORI}

Polimer adalah suatu zat kimia yang terdiri dari molekul-molekul yang besar dengan karbon dan hidrogen sebagai molekul utamanya. Bahan polimer berasal dari limbah plastik yang didaur ulang, kemudian dicampur dengan bahan kimia lainnya. Penggunaan bahan tersebut sekaligus bertujuan memanfaatkan limbah plastik, di samping mencari alternatif pengganti semen. Ketika itu harga semen masih melonjak-lonjak.

"DJUANDA SURAATMADJA. Penemu Beton Polimer yang Ramah Lingkungan”

Beton polimer adalah material komposit dimana seluruh perekatnya terdiri dari polimer organik sintetis. Komposit ini biasa dikenal dengan sebutan beton resin sintetis, beton resin plastik atau beton resin. Pemakaian polimer menggantikan semen portland menyebabkan peningkatan biaya, untuk itu penambahan polimer akan efektif dan sepadan dengan kenaikan biaya pada aplikasi yang sesuai dimana biaya tinggi dapat setara dengan properties yang superior yang dituntut, terkompensasi dengan rendahnya biaya pekerja atau pemakaian energi yang rendah selama proses dan pemeliharaan.

Beton polimer terdiri dari filler mineral (sebagai contoh adalah aggregate) dan perekat polimer yang bisa saja termoplastik tetapi polimer termosetting lebih sering dipakai. Ketika pasir digunakan sebagai filler, komposit ini disebut sebagai mortar polimer. Filler 
lain juga dapat digunakan termasuk batu halus, batu kerikil, kapur, bubuk silika, debu silika, granit, kwarsa, lempung expanded glass dan filler logam. Secara umum material yang kering, nonabsorbent dan padat dapat menjadi filler. Untuk memproduksi beton polimer, dilakukan pencampuran antara monomer atau prepolymer, hardener (cross linking agent), katalis dan filler. Bahan-bahan aditif juga ditambahkan seperti plasticizer dan fire retardant. Terkadang ditambahkan silane couplingagent untuk meningkatkan kekuatan ikatan matriks polimer dan filler.

Beton polimer memiliki sifat kedap air, tidak terpengaruh sinar ultraviolet, tahan terhadap larutan agresif seperti bahan kimia serta kelebihan lainnya. Yang lebih istimewa lagi, beton polimer bisa mengeras di dalam air sehingga bisa digunakan untuk memperbaiki bangunan di dalam air.

\section{CARA KERJA}

Alat Penelitian:

- Cetakan kubus $15 \times 15 \times 15 \mathrm{~cm}$

- Alat Uji Tekan

- Timbangan Digital dan Analog

- Sarung Tangan anti air

- Pipet dan Gelas Ukur

- Palu Karet dan alat Pengaduk

- Kuas dan kain Lap

Bahan Penelitan:
- $\quad$ Epoxy Resin + Hardener

- Polymer Polygrout + Inisiator

- Agregat Kasar Lolos 3/4"

- $\quad$ Agregat Halus

Metode Pengujian:

- Letakkan benda uji pada mesin tekan secara centris

- Jalan mesin tekan dengan penambahan beban konstan berkisar antara 2 sampai $4 \mathrm{~kg} / \mathrm{cm}^{2} /$ detik;

- Lakukan pembebanan sampai benda uji menjadi hancur dan catatlah beban maksimum yang terjadi;

- Gambar bentuk pecah dan catatlah keadaan benda uji.

\section{HASIL DAN PEMBAHASAN}

Berdasarkan grafik kuat tekan beton yang bersumber dari hasil analisis di atas, nilai pencapaian kuat tekan beton dengan campuran epoxy resin lebih tinggi daripada campuran dengan polymer polygrout. Beton dengan campuran epoxy resin + kerikil memiliki nilai kuat tekan yang paling tinggi di antara kadar lainnya dengan nilai kuat tekan 57,2 Mpa. Namun beton dengan campuran polymer polygrout + kerikil memiliki nilai kuat tekan paling rendah 29,5 Mpa. Dari hasil uji kuat tekan beton umur 2 hari tanpa perawatan menunjukan bahwa beton dengan campuran epoxy dan Polymer Polygrout memiliki nilai kuat tekan yang tinggi dengan nilai paling 
rendah 45,7 Mpa dari campuran epoxy + $75 \%$ agregat kasar $+25 \%$ agregat halus, dan 36,6 Mpa dari campuran Polymer Polygrout $+75 \%$ agregat kasar $+25 \%$ agregat halus. Oleh karena itu dapat disimpulkan bahwa beton polimer (beton tanpa semen) sangat mempengaruhi nilai kuat tekan beton menjadi lebih tinggi/ high strength. Karena nilai kuat tekan beton bertambah dari nilai rencana.

\begin{tabular}{|c|c|c|c|c|}
\hline \multirow{4}{*}{ 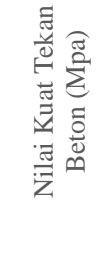 } & \multicolumn{4}{|c|}{$\mathrm{Fc}^{\prime}=\mathrm{Mpa}$} \\
\hline & \multirow{2}{*}{$\begin{array}{r}100,0 \\
50,0\end{array}$} & 57,2 & 45,7 & 49,0 \\
\hline & & 295 & 36,6 & $\overrightarrow{9,0}$ \\
\hline & 0,0 & 29, & 2 & 3 \\
\hline$\simeq-\mathrm{Ep}$ & esin & 57,2 & 45,7 & 49,0 \\
\hline$-\mathrm{Po}$ & Polygrout & 29,5 & 36,6 & 39,0 \\
\hline
\end{tabular}

Beton polimer hanya direkomendasikan untuk beton repair, karena penggunaan biaya yang tinggi sehingga pemilihan perekat beton masih menggunakan semen pada umumnya. Namun semua tak luput dari sebuah formula baru yang dapat menyetarakan biaya kebutuhan epoxy sama dengan kebutuhan semen.

\section{DAFTAR PUSTAKA}

Tandean, E. 2017. "Pengaruh Penggunaan Zat Epoxy Terhadap Beton Normal Dengan Bahan Tambah Kaca Sebagai Substitusi Agregat Halus". Yogyakarta: Universitas Atma Jaya Yogyakarta

Puspitasari, Bunga Sri, dkk. 2013. "Studi Eksperimental Pengaruh Penambahan Resin Pada Agregat Kasar Terhadap Kekuatan Beton". Semarang: Universitas Diponegoro Semarang

Suraatmadja, D. Penemu beton polimer yang ramah lingkungan di https://situspenemu.blogspot.com/2013/ 12/penemu-beton-polimer-yangramah.html (akses Januari 2019)

Wikipedia.Epoxy:

http://en.wikipedia.org/wiki/epoxy
Surdia, Tata dan Shinroku Saito. 1999. "Pengetahuan Bahan Teknik". Jakarta: PT. Pradnya Paramita

Haryono, UT. 2010. "Polimer Termoplastik dan Termosetting" di http://rinapuspita996.blogspot.com/2014 /02/polimer-termoplastik-dan termosetting.html (akses januari 2019)

Suraatmadja, D dkk. 1996. "FALPO, Beton Polimer Bobot Ringan”. Prosiding Pertemuan Ilmiah Sains Materi 1996

Badan Standardisasi Nasional. SNI 1947:2011. Cara Uji Kuat Tekan Beton Dengan Benda Uji Silinder

Badan Standardisasi Nasional. SNI 1970:2008. Cara Uji Berat Jenis dan Penyerapan Air Agregat Halus

Badan Standardisasi Nasional. SNI 031969-1990. Metode Pengujian Berat Jenis Dan Penyerapan Air Agregat Kasar

Pusjatan, Balitbang PU. SNI 03-19681990. Metode Pengujian Tentang Analisis Saringan Agregat Halus Dan Kasar

Pusjatan, Balitbang PU. SNI 03-19701990. Metode Pengujian Berat Jenis Dan Penyerapan Air Agregat Halus. 